\title{
Bir Ameliyathanenin İklimlendirilmesinde Üfleme Hızının Sayısal Analizi ve Modellenmesi
}

\author{
Yasin Polat ${ }^{1}$, Hüseyin Yağ $1^{2}$, Yıldız Koç ${ }^{3 *}$ \\ ${ }^{1}$ Mustafa Kemal Üniversitesi, Fen Bilimleri Enstitüsü, Makine Mühendisliği Anabilim Dalı, Hatay, Türkiye (ORCID: 0000-0002-1255-9990) \\ 2 İskenderun Teknik Üniversitesi, Mühendislik ve Doğa Bilimleri Fakültesi Makine Mühendisliği Bölümü, Hatay, Türkiye (ORCID: 0000-0002-9777-0698) \\ 3 İskenderun Teknik Üniversitesi, Mühendislik ve Doğa Bilimleri Fakültesi Makine Mühendisliği Bölümü, Hatay, Türkiye (ORCID: 0000-0002-2219-645X)
}

(İlk Geliş Tarihi 3 Haziran 2019 ve Kabul Tarihi 16 Temmuz 2019)

(DOI: 10.31590 /ejosat.573528)

ATIF/REFERENCE: Polat, Y. Yağlı, H. \& Koç, Y. (2019). Bir Ameliyathanenin İklimlendirilmesinde Üfleme Hızının Sayısal Analizi ve Modellenmesi. Avrupa Bilim ve Teknoloji Dergisi, (16), 605-619.

\section{Öz}

Ameliyathane ortamlarına giren ve çıkan personel gibi kaçınılamaz mikroorganizma kaynaklarından gelen zararlıların dezenfektanlar ile verdiği zararların minimize edilmesi mümkün iken mikroorganizmaları zararlı seviyenin altında tutabilmek için ortamın uygun standartlarında havalandırmasının ve iklimlendirmesinin kritik öneme sahip olduğu açıkça görülmektedir. Bu nedenle bu çalışma kapsamında, bir ameliyathanenin iklimlendirilmesi ve havalandırılması esnasında hava akışından kaynaklı mikroorganizmaların çoğalmasını engellemek için hava akışı ANSYS Fluent programı kullanılarak sayısal olarak analiz edilmiştir. Çalışma kapsamında ameliyathane için tavandan üfleme ve duvardan emme menfezli Model-1 ve aseptizör cihazının kullanıldığı Model-2 bir arada ele alınmış ve hava akış yönü ve hava hız açısından elde edilen analiz sonuçları birbiri ile kıyaslanmıştır. Tasarlanan her iki iklimlendirme sistemi de ocak ve temmuz ayları için analiz edilmiştir. Elde edilen sonuçlar bir arada değerlendirildiğinde, monitör, cerrahi alet masası, ilaç dolabı, anestezi makinası gibi cihazlar tavandan askılı olmadığı için her iki model de hava sirkülasyonunun engellendiği ve ölü akış bölgelerinin oluştuğu görülmüştür. Model-2'de bulunan aseptizör cihazı, standartlarda belirtildiği gibi laminer hava akımı oluşturmamakta ve enfeksiyon riski oluşumunu artırmaktadır. Bu nedenle, Model-2 ile kıyaslandığında, Model-1'de ki tavandan üfleme kenarlardan emme yapan iklimlendirme sisteminin ameliyathane iklimlendirmelerinde daha uygun olduğu görülmüsstür.

Anahtar Kelimeler: Ameliyathane, İklimlendirme, Aseptizör, Modelleme, Fluent, Hava Hızı Analizi.

\section{Numerical Analysis and Modeling of Air Flow Velocity in Air Conditioning of an Operating Room}

\begin{abstract}
While it is possible to minimize the damage caused by inevitable sources such as the personnel entering and leaving to the operating environment, it is obvious that the ventilation and air conditioning of the operating room environment are critical in order to keep the microorganisms below the harmful level. For this reason, airflow velocity was analyzed numerically using the ANSYS Fluent program to prevent the proliferation of microorganisms coming from the air stream during the air conditioning and ventilation of an operating room. Within the scope of the study, the Model-1, which uses ceiling blowing and wall suction air conditioning system and Model-1, which uses aseptizer device was analysed and the results obtained from the air flow direction and air velocity were compared with each other. Both air conditioning systems were analyzed for January and July. When the results were evaluated together, devices such as monitor, surgical instrument table, medicine cabinet, anesthesia machine were not suspended from the ceiling. Because of that both models prevented air circulation and dead flow regions were formed. Aseptizing device used in Model-2, as specified in the standards does not create laminar air flow and increase the risk of infection. Therefore, the most convenient air conditioning system ceiling from was seen as Model-1.
\end{abstract}

Keywords: Operating Room, Air Conditioning, Aseptizer, Modelling, Fluent, Air Velocity Analysis.

\footnotetext{
* Sorumlu Yazar: İskenderun Teknik Üniversitesi, Mühendislik ve Doğa Bilimleri Fakültesi, Makine Mühendisliği Bölümü, Hatay, Türkiye, yildiz.koc@iste.edu.tr
} 


\section{Giriş}

Ameliyathaneler, önemli cerrahi operasyonların yapıldığı yerler olduğundan, hasta sağlığını tehlikeye atmayacak temiz odalar olmalıdır. Ameliyathanelerin temiz odalar olabilmesi için ortamdaki hava içerisinde bulunan partiküllerin tanecik sayısı ve çapı küçük olmalıdır [1]. Partiküllerin sayısını azaltmak için havalandırma sistemleri standartlara uygun olmalı, belirlenen hijyen kurallarına uymalı ve en iyi konfor şartlarında iklimlendirme yapılmalıdır [2]. Ameliyathane ortamlarının havası saatte 20-30 kez değişmeli ve 0,5 mikronluk partiküllerin en az \%90'ı filtrelenmelidir [3].

Ortamdaki partikül ve zararlı mikroorganizmaların minimize edilmesinin yanı sıra ameliyathane ortamlarının iklimlendirilmesi esnasında çalışan personelin ve hastanın konforunun ve sağlı̆̆ı için gerekli iklimlendirme şartlarının en iyi şekilde sağlanması gereklidir [4]. İklimlendirmenin iyi bir şekilde yapılması için ortam havasının sıcaklığının istenilen şartlarda tutulmasının yanı sıra ortama üflenen iklimlendirme havasının akış yönünün ve akış hızının da personel ve hasta konforu göz önünde bulundurularak en iyi şekilde ayarlanması gereklidir [5]. Hava hızının fazla olması, ameliyathanede hasta ve çalışanlar için konforsuz bir ortamın oluşmasına neden olmasının yanı sıra havalandırma sistemi üzerinde de aşıı bir 1sı yükü oluşmasına neden olur [6]. Ortam havalandırması ve iklimlendirilmesi esnasında ihtiyaç duyulan ısı yüküne ek olarak sistemin aşırı çalışmasına paralel olarak ısınan sistemden kaynaklanan fazla 1sı oluşumu ortam havasının ısısını ve nemini kayda değer oranlarda etkilemekte ve ortamdaki mikroorganizmaların artmasına neden olmaktadır [1]. Ameliyathane havasındaki mikroorganizmaların sayısının artmasına neden olan diğer etkenler ameliyathaneye giriş çıkış yapan personel sayısı, ortamdaki partiküllerin tam olarak temizlenememesi, ameliyathane dışarısındaki havanın ameliyathaneye girmesi olarak siralanabilir [7].

Ameliyathane ortamlarındaki mikroorganizmaların artışına neden olan birçok etmenin yanı sıra ortam iklimlendirme ve havalandırma sistemindeki hava akış yönü ve hava akış hızı da mikroorganizmaların sayılarındaki istenmeyen bu artışın en önemli nedenlerinden birsidir. Süngü (2007), yapmış olduğu deneysel çalışmada aynı kirliliğe sahip 2 besi kabını laminer ve türbülanslı iki farklı ortama koymuştur. Türbülanslı akışta 200'e yakın mikroorganizma, laminer akışta ise sıfır mikroorganizma olduğunu gözlemlemiştir. Bu nedenle en azından ameliyat masasının üst tarafında laminer akış sağlanmasının gerekli olduğunu görmüştür [8]. Bu nedenle ameliyathanelerde kullanılan havalandırma ve iklimlendirme sistemlerinde havanın laminer akış şartlarını sağlaması istenmektedir.

Ameliyathanelerde enfeksiyon riskini artıran kaçınılamaz mikroorganizma kaynakları olsada (ameliyathane personeli gibi) bu enfeksiyon kaynaklarının biçoğunun ortama getirdiği zararlıların dezenfektanların kullanımı ile zararsız seviyelere indirilebilmesi mümkündür. Fakat, ortam havalandırması gibi dezenfektanlarla verilen zararların minimize edilemeyeceği durumlarında varlığı şüphesizidir. Bu nedenle, havalandırma sistemlerinden gelen mikroorganizmaları zararlı seviyenin altında tutabilmek için ortamın uygun standartlarda havalandırması ve iklimlendirmesi kritik öneme sahiptir. Ameliyathanelerde havalandırma ve iklimlendirme sistemlerinin tasarımı üzerine her ne kadar birçok çalışma bulunsa da bu çalışmaların çok az kısmının hava akışııı ve hava akışının ameliyathanedeki dağılımını incelemektedir.

Bu çalışmada, bir ameliyathanenin iklimlendirilmesi ve havalandırılması esnasında hava akışından kaynaklı mikroorganizmaların çoğalmasını engellemek için hava akışı ANSYS Fluent programı kullanılarak sayısal olarak analiz edilmiştir. Çalışma kapsamında ameliyathane için tavandan üfleme ve duvardan emme menfezli Model-1 ve aseptizör cihazının kullanıldığı Model-2 bir arada ele alınmış ve hava akış yönü ve hava hız açısından elde edilen analiz sonuçları birbiri ile kıyaslanmıştır. Tasarlanan her iki iklimlendirme sistemi de ocak ve temmuz ayları için analiz edilmiştir.

\section{Ameliyathanelerin İklimlendirilmesinin Önemi}

Hava içerisindeki mikroorganizmaların solunum ve açık yaralarla direk temasa geçmesi hastalık bulaşma riskini en üst seviyelere çıkarmaktadır [9]. Ameliyathane gibi cerrahi operasyonların yapıldığı yerlerde bu durumla oldukça fazla karşılaşılmaktadır. Ameliyathanelerde enfeksiyon riskinin artmasında en önemli nedenlerden birisi ameliyathane personelleridir [10]. Personellerin ortam içerisindeki hareketleri, kıyafetleri, sağlık durumları enfeksiyon riskinin artmasında oldukça etkilidir. Bunun dışında hava akış yönü, ortamda bulunan havanın basıncı, cerrahi aletlerin temizliği ameliyathanede enfeksiyon riskini artıran diğer önemli nedenlerdendir [11].

Ameliyathanelerde enfeksiyon riskini en aza indirgemek için iklimlendirme ve havalandırma sistemlerinin standartlara uygun şekilde yapılması gerekmektedir. Kullanılan iklimlendirme sistemlerinde HEPA filtreler kesinlikle bulunmalıdır. İklimlendirme sisteminde üçüncü kademede bulunan HEPA filtreler, mikroorganizmaların temizlenmesinde \%99,98'e kadar verimlilik gösterebilmektedirler [12,13]. İklimlendirme ve havalandırma sistemlerinde birinci kademede elyaf filtreler kullanılırken ikinci kademede torba filtreleri kullanılmaktadır [11].

Ameliyathanelerin iklimlendirilmesinde kullanılan laminer akış cihazı birçok HEPA filtrenin bir araya getirilmesinden oluşan sistemlerdir. Bu sistemler, cerrahi alan üzerinde laminer hava akışı sağlayarak cerrahi alanda mikroorganizmaların çoğalmasını engellerken cerrahi alandan mikroorganizmaların ortalama $0,25 \mathrm{~m} / \mathrm{s}$ hızla uzaklaştıılmasını sağlamaktadırlar [11,13]. Bu nedenle laminer akış cihazları ortamın daha hijyenik olmasını sağlamaktadırlar. Birçok ülkede ameliyathanelerde kullanılmakta olan laminer hava akışlı iklimlendirme sistemleri, diğer iklimlendirme sistemlerine kıyasla daha yüksek verime sahip olsa da pahalı ve sık sık bakıma ihtiyaç duyan sistemlerdir [14].

Ameliyathanelerde kullanılan bir diğer iklimlendirme sistemi olan paket tip hijyenik iklimlendirme sistemleri de ortamın basıncının istenildiği gibi ayarlanmasını sağlamakta ve ortamı yüksek kalitede hava ile beslemektedirler [15]. Ayrıca, ortamda bulunan havanın sıcaklığını, nemini, basıncını ayarlayarak istenilen havanın elde edilmesini mümkün kılmaktadırlar. 
Her iki iklimlendirme sisteminin bakımı zamanında ve düzenli bir şekilde yapılması sonucunda 15-20 yıl boyunca kullanabilmektedirler. Dahası, her iki iklimlendirme sisteminde de filtrelerde yakalanmayan mikroorganizmaları etkisiz hale getiren ultraviyole sistem bulunmaktadır [11]

\section{Tasarlanan İklimlendirme ve Havalandırma Sistemlerinin Tanıtımı}

Çalışma kapsamında havalandırma ve iklimlendirmesi yapılacak olan ameliyathanenin ölçüleri 600x600x290 cm olarak kabul edilmiştir. Ameliyathane için tavandan üflemeli ve duvardan emmeli iklimlendirme sistemi (Model-1) ve aseptizörlü iklimlendirme sistemi (Model-2) olmak üzere iki farklı iklimlendirme sistemi tasarlanmıştır. Tasarlanan her iki iklimlendirme sistemi de ocak ve temmuz ayları için analiz edilmiş̧ir.

\subsection{Tavandan Üflemeli ve Duvardan Emişli İklimlendirme ve Havalandırma Sistemi (Model-1)}

Model-1'de, 6 adet 57x59 cm ölçülerinde üfleme menfezi ile tavandan üfleme yapılmaktadır ve yan duvarlara 14x29 cm ölçülerinde emme menfezleri yerleştirilerek ortam havasının emdirilmesi sağlanmıştır. Ocak ve temmuz aylarının her ikisi içinde Model-1 üfleme hızı $0,4 \mathrm{~m} / \mathrm{s}$ olarak kabul edilmiştir. Model-1'de kullanılan cihazların ve ameliyathanede bulunan insanların yerleşim planının şematik gösterimi Şekil 1'de verilmektedir.

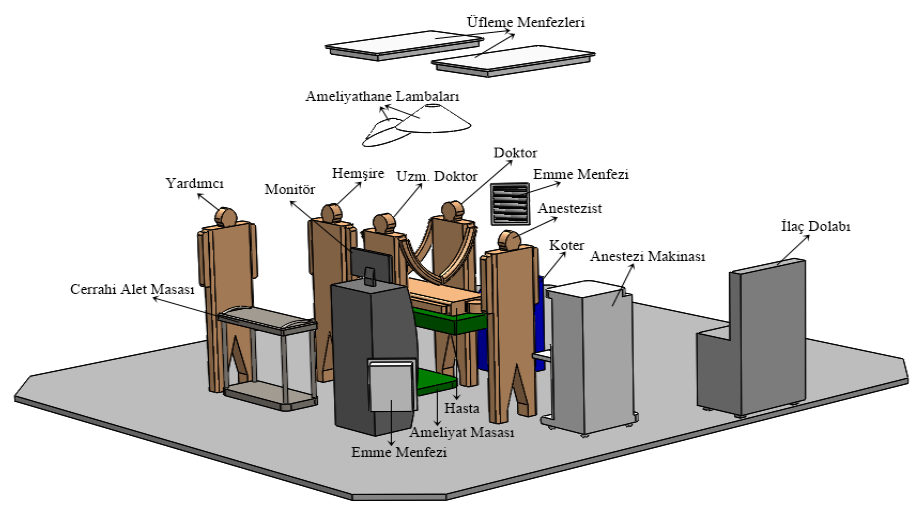

Şekil 1. Model-1'de kullanılan cihazların ve ameliyathanede bulunan insanların yerleşim planının şematik gösterimi

İklimlendirme ve havalandırma sisteminin tasarımında kullanılan cihazlar ve ameliyathanelerde genel olarak bulunan personel ve hasta sayıları göz önünde bulundurularak her birinin ölçüleri ve ısı yayım değerleri belirlenmiştir. Model-1'de kullanılan cihazların ve ameliyathanede bulunan insanların ölçüleri ile 1sı yayım değerleri Tablo 1'de verilmektedir.

Tablo 1. Model-1'de kullanılan cihazların ve ameliyathanede bulunan insanların ölçüleri ile ısı yayım değerleri

\begin{tabular}{llc}
\hline \hline & Ölçüler $(\mathbf{c m})$ & Yüzey Sıcaklı̆̆ı $\left({ }^{\circ} \mathbf{C}\right)$ \\
\hline \hline Ameliyat Masası & $190 \times 60 \times 70$ & Yok \\
\hline 1. Cerrahi Işık & Yarı Küre $($ Çap=70 ve Yükseklik=25) & 50 \\
\hline 2. Cerrahi Işık & Yarı Küre (Çap=50 ve Yükseklik=20) & 40 \\
\hline Cerrahi Kadro & $20 \times 66 \times 175$ & 37 \\
\hline Cerrahi Alan & $20 \times 25$ & 37 \\
\hline Hasta & $20 \times 60 \times 175$ & 20 \\
\hline Anestezi Makinesi & $60 \times 65 \times 145$ & 70 \\
\hline Koter Cihazı & $38 \times 38 \times 103$ & 45 \\
\hline Monitör & $10 \times 40 \times 35$ & 40 \\
\hline Monitör Standı & $45 \times 50 \times 130$ & 40 \\
\hline Cerrahi Alet Masası & $60 \times 95 \times 85$ & Yok \\
\hline İlaç Dolab1 & $50 \times 70 \times 170$ & Yok \\
\hline Üfleme menfezi & $57 \times 59$ & Yok \\
\hline Emme menfezi & $14 \times 29$ & Yok \\
\hline \hline
\end{tabular}




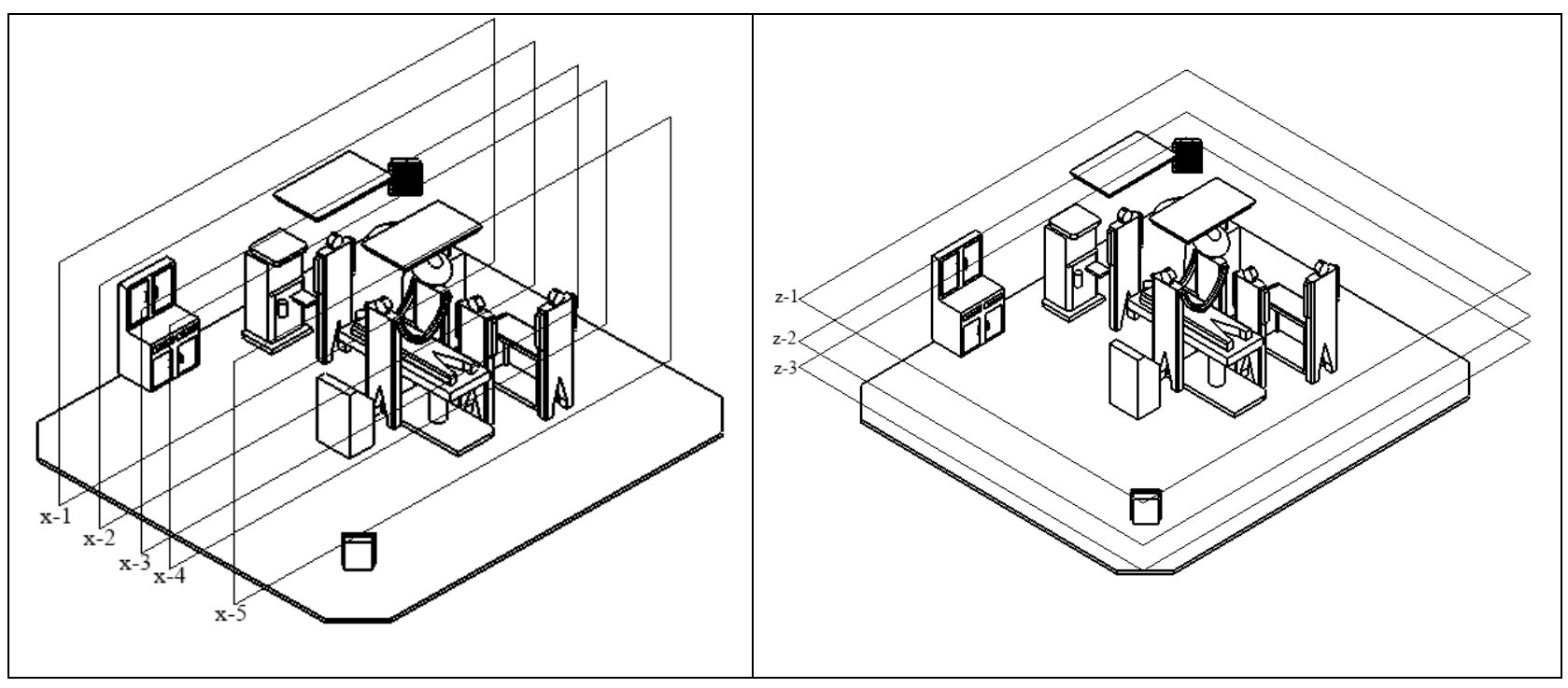

Şekil 2. Model-1 için x-düzleminde ve z-düzleminde alınan kesit görünüşleri

Cerrahi kadronun etrafında, cerrahi alan etrafında ve üfleme menfezleri çıkışlarında oluşan hava akışlarının detaylı bir şekilde incelenmesi için Model-1 için elde edilen analiz sonuçları x-düzleminde 5 farklı kesit için ayrı ayrı incelenmiştir. Cerrahi alanın en üst bölgesinde, personelin baş seviyesinde ve cerrahi alanın en alt bölgesinde oluşan hava akımını inceleyebilmek için elde edilen veriler z-düzleminde 3 farklı kesitte incelenmiştir. Model-1 için x-düzleminde ve z-düzleminde alınan kesitler Şekil 2'de sistemin şematik gösterimi üzerinde verilmektedir.

\subsection{Aseptizörlü İklimlendirme ve Havalandırma Sistemi (Model-2)}

Model-2'de iklimlendirme ve havalandırma için aseptizör cihazı kullanılmıştır. Aseptizör cihazında 2 adet $54 x 54$ cm üfleme menfezi ile üfleme yapılmakta ve 2 adet $35 \times 60 \mathrm{~cm}$ emme menfezi ile ortam havası emdirilmektedir. Çalışma kapsamında kullanılan aseptizörlü iklimlendirme sisteminde sıcaklık $16{ }^{\circ} \mathrm{C}$ ile $25{ }^{\circ} \mathrm{C}$ arasında ayarlanabilirken bağ 11 nem \%30 ile \%70 arasında ayarlanabilmektedir. Ocak ve temmuz aylarının her ikisi içinde Model-2'de üfleme hızı $1 \mathrm{~m} / \mathrm{s}$ olarak kabul edilmiştir. Model-2'de kullanılan cihazların ve ameliyathanede bulunan insanların yerleşim planının şematik gösterimi Şekil 3 'de verilmektedir.

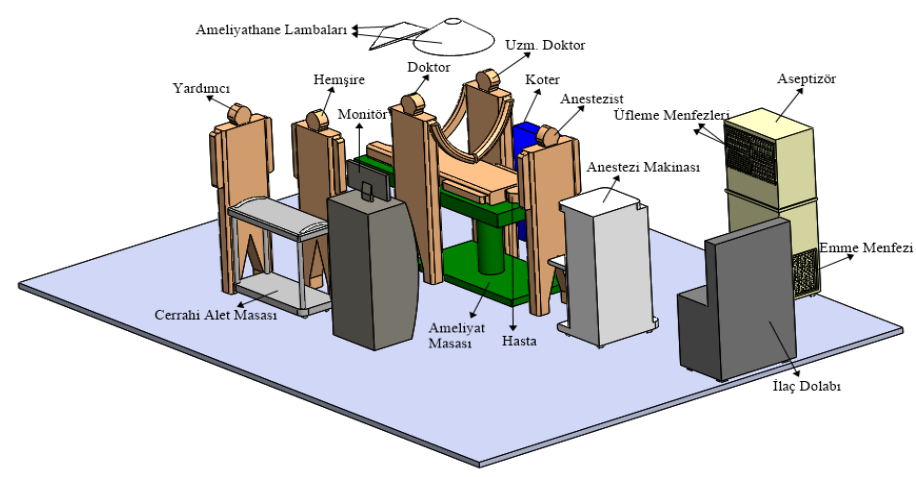

Şekil 3. Model-2'de kullanılan cihazların ve ameliyathanede bulunan insanların yerleşim planının şematik gösterimi

İklimlendirme ve havalandırma sisteminin tasarımında kullanılan cihazlar ve ameliyathanelerde genel olarak bulunan personel ve hasta sayıları göz önünde bulundurularak her birinin ölçüleri ve 1sı yayım değerleri belirlenmiştir. Model-2'de kullanılan cihazların ve ameliyathanede bulunan insanların ölçüleri ile ısı yayım değerleri Tablo 2'de verilmektedir. 
Tablo 2. Model-2'de kullanılan cihazların ve ameliyathanede bulunan insanların ölçüleri ile ısı yayım değerleri

\begin{tabular}{llc}
\hline \hline & Ölçüler $(\mathbf{c m})$ & Yüzey Sıcaklı̆̆ı $\left({ }^{\circ} \mathbf{C}\right)$ \\
\hline \hline Ameliyat Masası & $190 \times 60 \times 70$ & Yok \\
\hline 1. Cerrahi Işık & Yarı Küre $($ Çap=70 ve Yükseklik=25) & 50 \\
\hline 1. Cerrahi Işık & Yarı Küre (Çap=50 ve Yükseklik=20) & 40 \\
\hline Cerrahi Kadro & $20 \times 66 \times 175$ & 37 \\
\hline Cerrahi Alan & $20 \times 25$ & 37 \\
\hline Hasta & $20 \times 60 \times 175$ & 20 \\
\hline Anestezi Makinesi & $60 \times 65 \times 145$ & 70 \\
\hline Koter Cihazı & $38 \times 38 \times 103$ & 45 \\
\hline Monitör & $10 \times 40 \times 35$ & 40 \\
\hline Monitör Standı & $45 \times 50 \times 130$ & 40 \\
\hline Cerrahi Alet Masası & $60 \times 95 \times 85$ & Yok \\
\hline İlaç Dolab1 & $50 \times 70 \times 170$ & Yok \\
\hline Aseptizör Cihazı & $55 \times 135 \times 220$ & Yok \\
\hline \hline
\end{tabular}

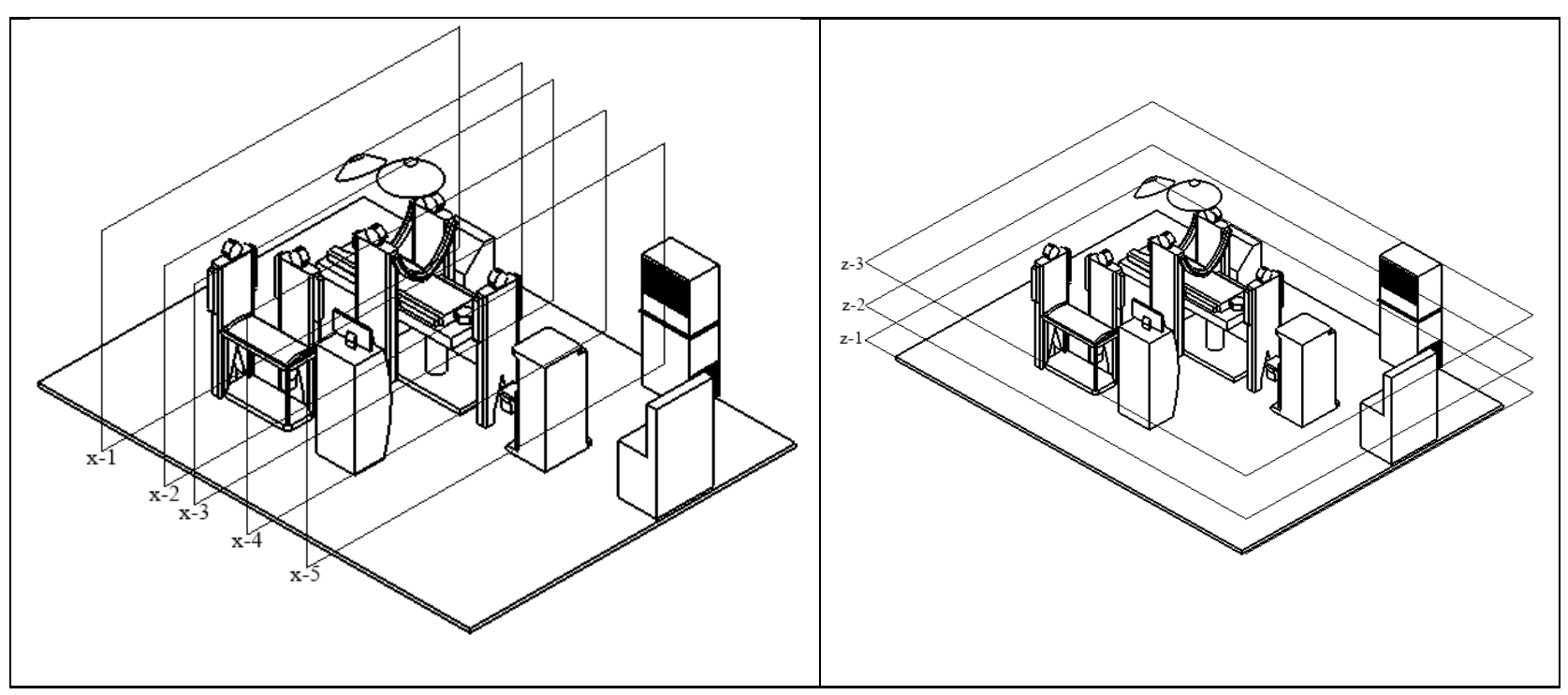

Şekil 4. Model-2 için x-düzleminde ve z-düzleminde alınan kesit görünüşleri

Cerrahi kadronun etrafında, cerrahi alan etrafında ve üfleme menfezleri çıkışlarında oluşan hava akışlarının detaylı bir şekilde incelenmesi için Model-2 için elde edilen analiz sonuçları x-düzleminde 5 farklı kesit için ayrı ayrı incelenmiştir. Cerrahi alanın en üst bölgesinde, personelin baş seviyesinde ve cerrahi alanın en alt bölgesinde oluşan hava akımını inceleyebilmek için elde edilen veriler z-düzleminde 3 farklı kesitte incelenmiştir. Model-2 için x-düzleminde ve z-düzleminde alınan kesitler Şekil 4'de sistemin şematik gösterimi üzerinde verilmektedir.

\section{Matematiksel Model ve Kabuller}

Tasarlanmış olan her iki iklimlendirme sisteminin analizi için ANSYS Fluent 6.3 programı kullanılmıştır. Program içeriğinde ameliyathane modelleme için kullanılabilecek herhangi bir çizim programı bulunmadığından dolayı sistemin tasarımı ve çizimi Fluent 6.3 programı ile uyumlu olan Gambit çizim programı ile yapılmış̦tır. Ameliyathanede bulunan ekipmanlar ve cerrahi kadronun yerleşimi, Memarzadeh ve Manning'in çalışmalarında kullandıkları yerleşim planı ile aynı kabul edilmiş ve buna göre yapılmıştır $[7,16]$. 

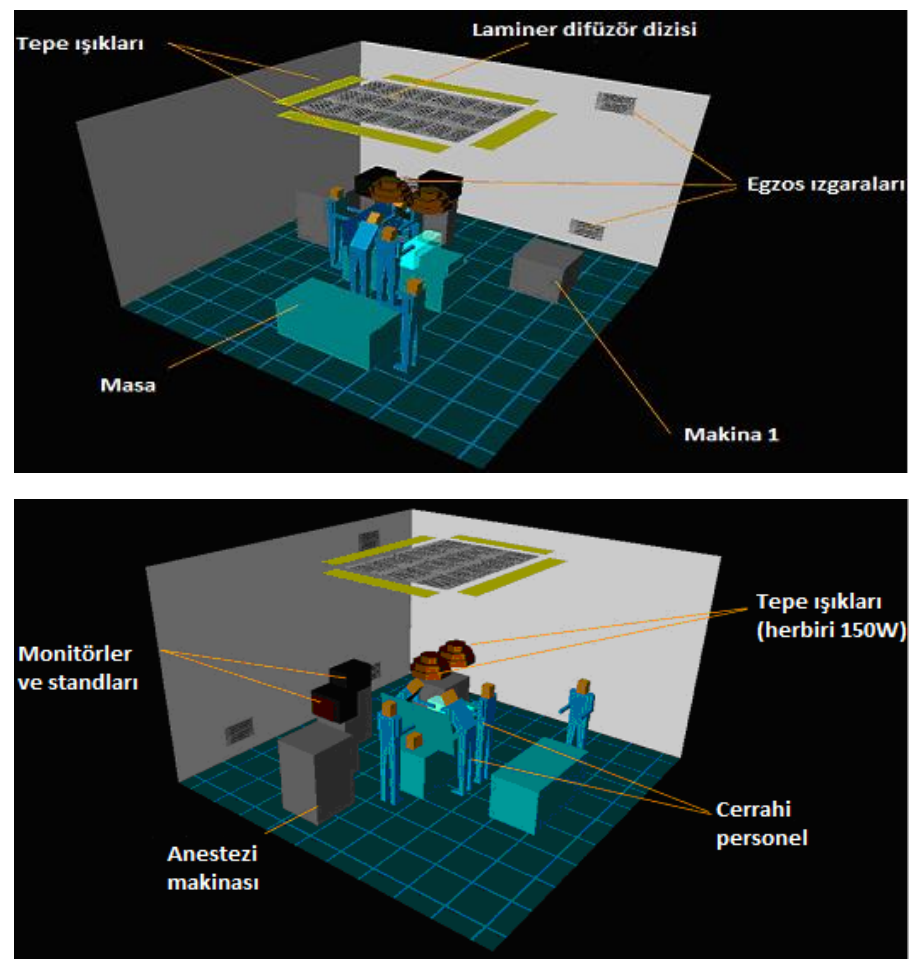

Şekil 5. Memarzadeh ve Manning'in çalışmalarında kullandıkları yerleşim plan [16]

Çalışma kapsamında hava ideal gaz, sıkıştırılamaz ve viskoz olarak kabul edilmiştir. Yapılan kabuller doğrultusunda kararsız akım için süreklilik denklemi, hareket denklemleri ve türbülanslı akım oluşması durumunda k-E türbülanslı denklemleri belirlenmiştir. Sürekli rejim şartlarında üç boyutlu sıkıştırılamaz laminer akım için süreklilik denklemi;

$\frac{\partial u}{\partial x}+\frac{\partial v}{\partial y}+\frac{\partial w}{\partial z}=0$

ile ifade edilirken burada $u, v$ ve $w$ sırasıyla $\mathrm{x}$, y ve $\mathrm{z}$ doğrultusundaki hareket hızını ifade etmektedir. Süreklilik şartlarında momentum denklemleri;

$\frac{\partial u}{\partial t}=0$

$\frac{\partial v}{\partial t}=0$

$\frac{\partial w}{\partial t}=0$

olarak ifade edilmektedir. $\mathrm{x}$ doğrultusunda;

$u \frac{\partial u}{\partial x}+v \frac{\partial u}{\partial y}+w \frac{\partial u}{\partial z}=-\frac{1}{\rho} \frac{\partial P}{\partial x}+\mu\left(\frac{\partial^{2} u}{\partial x^{2}}+\frac{\partial^{2} u}{\partial y^{2}}+\frac{\partial^{2} u}{\partial z^{2}}\right)$

y doğrultusunda;

$u \frac{\partial v}{\partial x}+v \frac{\partial v}{\partial y}+w \frac{\partial v}{\partial z}=-\frac{1}{\rho} \frac{\partial P}{\partial y}+\mu\left(\frac{\partial^{2} v}{\partial x^{2}}+\frac{\partial^{2} v}{\partial y^{2}}+\frac{\partial^{2} v}{\partial z^{2}}\right)+g \beta\left(T-T_{1}\right)$

$\mathrm{z}$ doğrultusunda;

$u \frac{\partial w}{\partial x}+v \frac{\partial w}{\partial y}+w \frac{\partial w}{\partial z}=-\frac{1}{\rho} \frac{\partial P}{\partial z}+\mu\left(\frac{\partial^{2} w}{\partial x^{2}}+\frac{\partial^{2} w}{\partial y^{2}}+\frac{\partial^{2} w}{\partial z^{2}}\right)$

$\mathrm{Bu}$ eşitliklerde; $\beta$ ısıl genleşme katsayısını, $T$ ortam sıcaklığını ve $T_{1}$ işlem sırasındaki sıcaklığı ifade etmektedir. Denklemlerin sınır şartları daha önceden ANSYS Fluent 6.3 programı tarafından belirlenen sınır şartları ile aynı kabul edilmiştir.

Denklemleri çözmek için basit iterasyon yöntemi ve kapalı şema çözümleme yöntemi kullanılmıştır. Basit iterasyon yöntemi kararlı ve kararsız akımlar için kullanılmaktadır. Yapılan çalışmada akım lineer olmayan ve kararsız olduğu için iteratif sonlu farklar çözüm yöntemi kullanılmıştır. Bunun nedeni ise kapalı hacimlerde akışkan hareketi problemlerinin çözümü için süreklilik ve momentum denklemlerinin aynı anda çözülmesinin gerekmesidir. Fakat bu iki denklem lineer olmayan kısmi diferansiyel denklemler olup analitik olarak çözülememektedirler. Denklemlerin çözülmesi için ilk önce cebirsel denklemlere dönüştürmek gerektiğinden, cebirsel denklemlere dönüştürmek için Taylor serisi kullanılmıştır. Dönüştürmelerde merkezi, ileri ve geri farklar kullanılmıştır. Taylor serisi ile elde edilen cebirsel denklemlerin çözümü için Succesive Under Relexation (SUR) metodu kullanılmıştır. Teoride çözüm akış alanının her bir noktası için yapılmalıdır fakat bu durum sonsuz sayıda nokta ve sonsuz sayıda denklem demektir. Bu nedenle akış alanı küçük bölgelere bölünerek bölgelerin kesiştiği noktalara elde edilen cebirsel denklemler uygulanmıştır. Çözümün hassasiyetini etkileyen 
durumlardan birisi cebirsel denklemlerin uygulandığı yerler olan dügüm noktalarıdır. Bu nedenle optimal düğüm (mesh) sayısının belirlenmesi çok önemlidir.

\section{Araştırma Bulguları ve Tartışma}

Ameliyathanelerde hasta ve personel sağlığı açısından en büyük riski oluşturan mikroorganizmaların çoğalmasını minimize etmek için dikkat edilmesi gereken en önemli parametrelerden biriside ameliyathanenin havalandırma ve iklimlendirme sisteminin doğru ve standartlara uygun şekilde tasarlanmasıdır. Bu nedenle bir ameliyathane için odadaki cihazlar, personel ve hasta sayıları dikkate alınarak iki farklı iklimlendirme sisteminin incelendiği bu çalışmada, tasarlanan sistemlerin ameliyathane içerisine üflediği ve emdiği havanın akım yönünün ve akım hızının tespiti ANSYS Fluent programı kullanılarak yapılmıştır. Tasarlanan sistemlerden elde edilen sonuçların yaz ve kış aylarında optimum değerlerde olması için sistem ocak ve temmuz aylarının her ikisi içinde ayrı ayrı analiz edilmiştir. Analiz sonuçlarının daha doğru ve detaylı incelenebilmesi için her bir iklimlendirme sistemi tasarımı için (Model-1 ve Model-2) x- düzleminde ve z- düzleminde sırasıyla 5 ve 3 farklı kesitte sonuçlar grafiksel olarak ele alınmıştır. Model-1 için hava üfleme hızı sabit ve 0,4 $\mathrm{m} / \mathrm{sn}$ olarak alınmıştır. Ocak ayı için Model-1'in kurulduğu ameliyathanenin x-1, x-2 ve x-3 düzlemlerinde hız vektörlerinin dağılımı Şekil 6 'da verilmektedir.

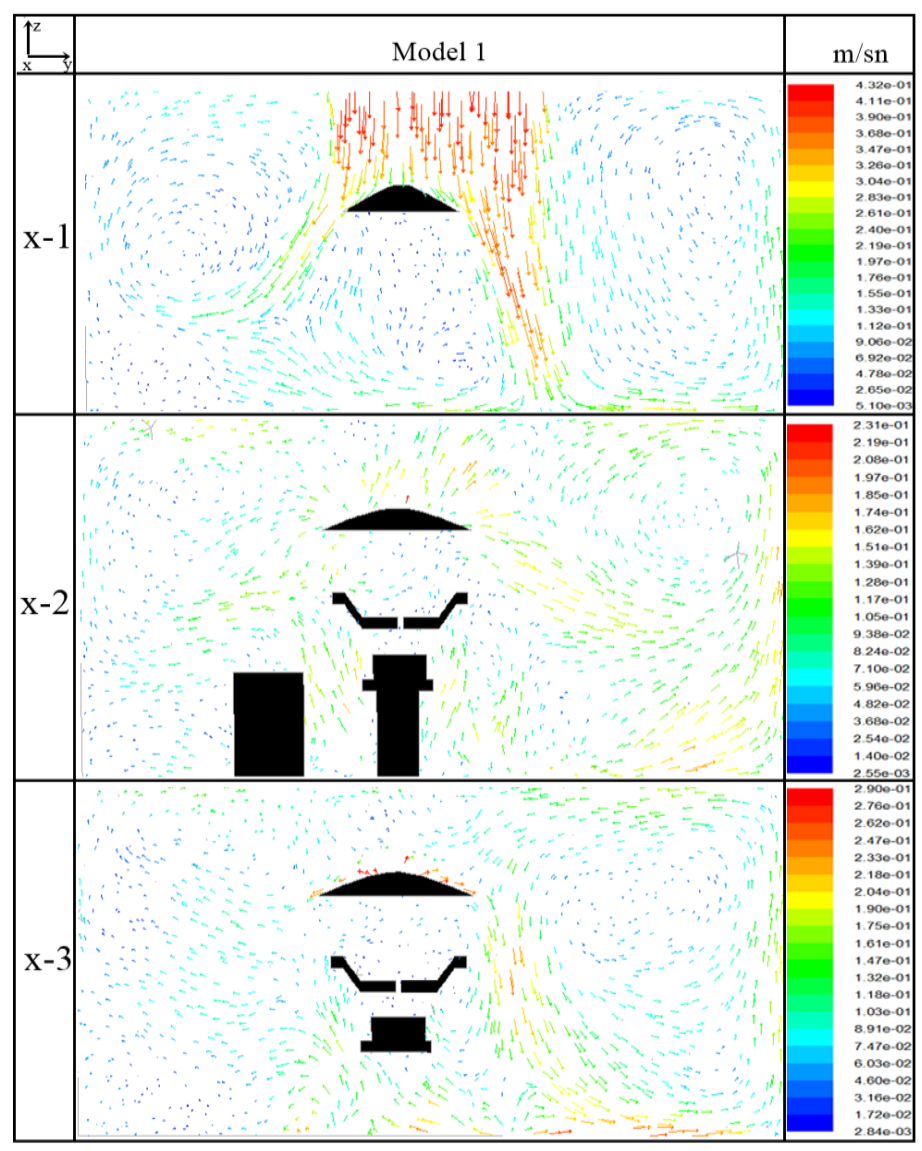

Şekil 6. Ocak ayı için Model-1 'in kurulduğu ameliyathanenin $x$-1, $x$-2 ve $x$-3 düzlemlerinde hız vektörlerinin dağıllmı

Şekil 6'da, $x$-1 düzleminde; üfleme menfezinden $0,4 \mathrm{~m} / \mathrm{sn}$ hızla çıkış yapan havanın ameliyathane lambasına çarpması sonucunda hızında azalma meydana geldiği görülmektedir. Yardımcı personelin bel seviyesinde, ayak ve baş bölgelerinde $0,04 \mathrm{~m} / \mathrm{sn}$ civarında, bel seviyesinde ise $0,24 \mathrm{~m} / \mathrm{sn}$ civarında düşük hızların oluştuğu görülmektedir. Sol alt bölgede ölü akış bölgelerinin oluştuğu görülmekte olup sağ tarafta ise saat yönünün tersinde akış bölgesi ve girdap oluşumu, sol üst bölgede saat yönünde ters akış ve girdap oluşumu orta kısımın alt bölgesinde küçük bir girdap oluşumu görülmektedir. Girdap oluşan bölgelerde ve ölü akış bölgelerinde hava sirkülasyonu engelleneceği için bu bölgelerde enfeksiyon üreme ve partikül çoğalma riski artmaktadır.

Şekil 6'da, x-2 ve x-3 düzlemlerinde; cerrahi alan üzerinde yaklaşık $0,01 \mathrm{~m} / \mathrm{s}$ durgun sayılabilecek bir hava akışı, cerrahi alet masası üzerinde de yaklaşık $0,05 \mathrm{~m} / \mathrm{sn}$ düşük hızlı türbülanslı akış bölgeleri oluşmuştur. Düşük hava hızları ve türbülanslı akış hastanın enfeksiyon kapma riskini arttırmaktadır. Bu nedenle hastanın enfeksiyon kapmaması için durgun hava akışının ve türbülanslı hava akışının ortadan kaldırılması gerekmektedir. Ocak ayı için Model-1'in kurulduğu ameliyathanenin x-4 ve x-5 düzlemlerinde hız vektörlerinin dağılımı Şekil 7'de verilmektedir. 


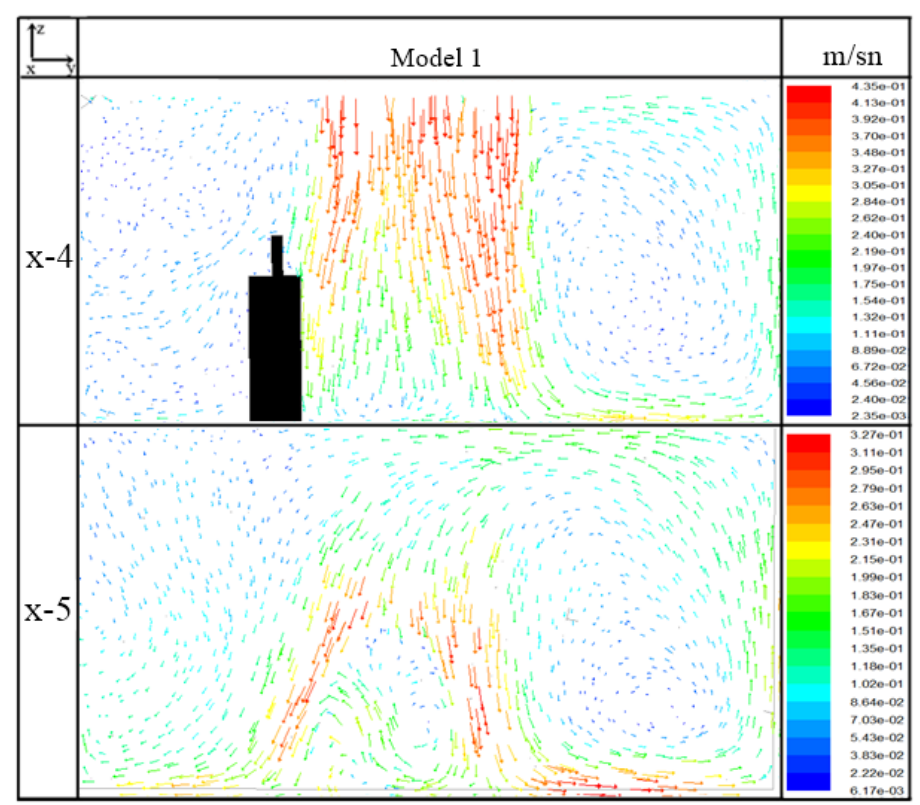

Şekil 7. Ocak ayı için Model-1'in kurulduğu ameliyathanenin x-4 ve x-5 düzlemlerinde hız vektörlerinin dăgllımı

Şekil 7'de, x-4 düzleminde; laminer akış bölgesi ve bu bölgenin sağ tarafında tabandan tavana kadar olan bölgede dönümlü hava gözlenmektedir. Sol tarafta monitör ve monitör standının, dönümlü hava bölgesinin ve laminer akış bölgesinin oluşumunu engellediği görülmektedir. Monitörün tavandan asılı olmasından dolayı sol kısımda da laminer akış bölgesi ve etrafında dönümlü hava bölgesi oluşturabileceği görülmektedir. Laminer akış bölgesi ve dönümlü hava bölgesi oluşumu ölü akış bölgelerinin oluşmasını önleyebilir.

Şekil 7'de, x-5 düzleminde; farklı hızlara sahip hava akış bölgeleri görülmektedir. Orta bölgede anestezi cihazına çarpan havanın oluşturduğu türbülanslı akış bölgesi ve sağ bölgede büyük bir hava döngüsü görülmektedir.

Şekil 7'de, x-1, x-4 ve x-5 düzlemlerinde laminer akış şartlarının sağlandığı fakat x-2 ve x-3 düzlemlerinde düşük hızlı türbülanslı akış bölgelerinin oluştuğu açıkça görülmektedir. Ocak ayı için Model-1'in kurulduğu ameliyathanenin z-1, z-2 ve z-3 düzlemlerinde hız vektörlerinin dağılımı Şekil 8'de görülmektedir.

Şekil 8'de, z-1 düzleminde; emme menfezlerinin girişinde çok yüksek emiş hızlarının olduğu görülürken diğer bölgelerde çok düşük hızların olduğu görülmüştür.

Şekil 8'de, z-2 ve z-3 düzlemlerinde; personeli rahatsız edecek emiş hava hızı bulunmamaktadır. Üfleme menfezleri çıkışında yaklaşık $0,35 \mathrm{~m} / \mathrm{sn}$ üfleme hızı gözlemlenmektedir. Bu üfleme hızı ile havanın ameliyathanedeki engellere çarpması sonucunda cerrahi alan üzerinde ve ameliyathanenin bazı bölgelerinde $0,05 \mathrm{~m} / \mathrm{sn}$ hızında ölü akış bölgeleri oluşturduğu görülmektedir. Temmuz ayı için Model-1'in kurulduğu ameliyathanenin x-1, x-2 ve x-3 düzlemlerinde hız vektörlerinin dağılımı Şekil 9'da verilmektedir. 


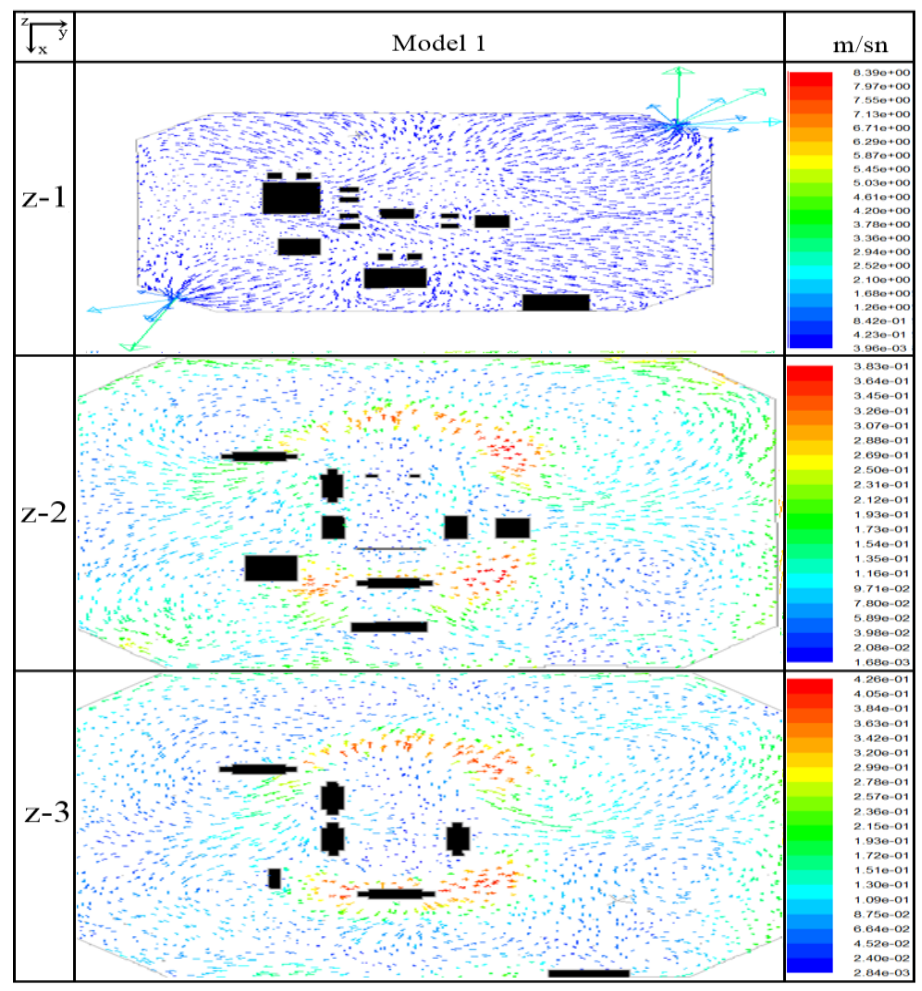

Şekil 8. Ocak ayl için Model-1 'in kurulduğu ameliyathanenin z-1, z-2 ve z-3 düzlemlerinde hız vektörlerinin dağıllmı

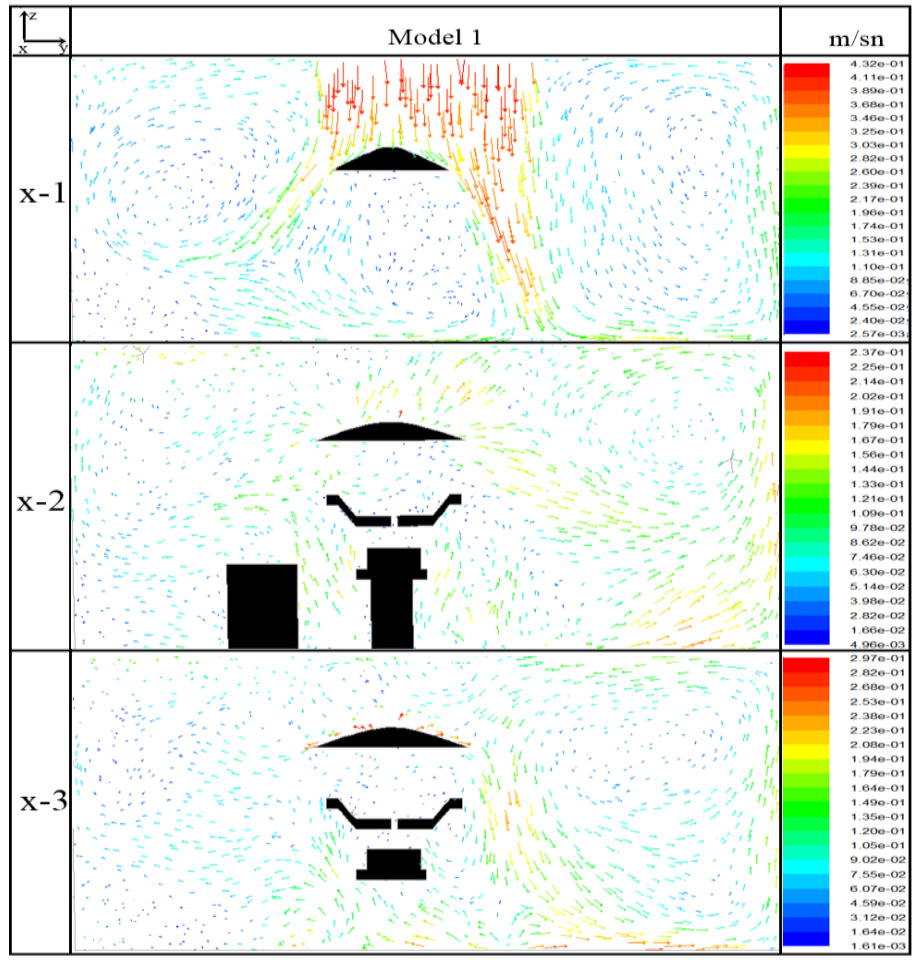

Şekil 9. Temmuz ayı için Model-1' in kurulduğu ameliyathanenin $x$-1, $x$-2 ve $x$-3 düzlemlerinde hız vektörlerinin dağllımı

Şekil 9'da, x-1 düzleminde; üfleme menfezi çıkışında $0,4 \mathrm{~m} / \mathrm{sn}$ hızla çıkan havanın ameliyathane lambasına çarpıp etrafa dağılmasıyla hızının düştüğü gözlenmiştir. Yardımcı personelin bel seviyesinde $0,15 \mathrm{~m} / \mathrm{sn}$, baş ve ayak kısımlarında yaklaşı $0,02 \mathrm{~m} / \mathrm{sn}$ hıza sahip havanın oluştuğu görülmektedir.

Şekil 9'da, $\mathrm{x}-2$ ve x-3 düzlemlerinde; cerrahi alan üzerinde $0,03 \mathrm{~m} / \mathrm{sn}$ civarında hemen hemen durgun hava akışı, cerrahi alet masası üzerinde ise $0,07 \mathrm{~m} / \mathrm{sn}$ civarında düşük hızlı türbülanslı akış bölgelerinin oluştuğu görülmektedir. Düşük hava hızları ve türbülanslı akış, hastanın enfeksiyon kapma riskini artırmaktadır. Farklı hava hızlarının oluşumuna üfleme menfezinden çıkan havanın ameliyathane içerisinde yer alan cihaz ve personellere çarpması ve emme menfezlerinin özelliği olan vakum etkisinin sebep olduğu düşünülmektedir. Ameliyathane lambalarının cerrahi alan üzerinde konumlandırılmasından dolayı koruma alanı üzerinde laminer akışın kesintiye uğradığı 
düzlemlerde açıkça gözlenmektedir. Ameliyat lambalarının uygun yere konumlandırılması durumunda laminer akışın istenilen düzeyde sağlanabileceği düşünülmektedir. Temmuz ayı için Model-1'in kurulduğu ameliyathanenin x-4 ve x-5 düzlemlerinde hız vektörlerinin dağılımı Şekil 10'da verilmektedir.

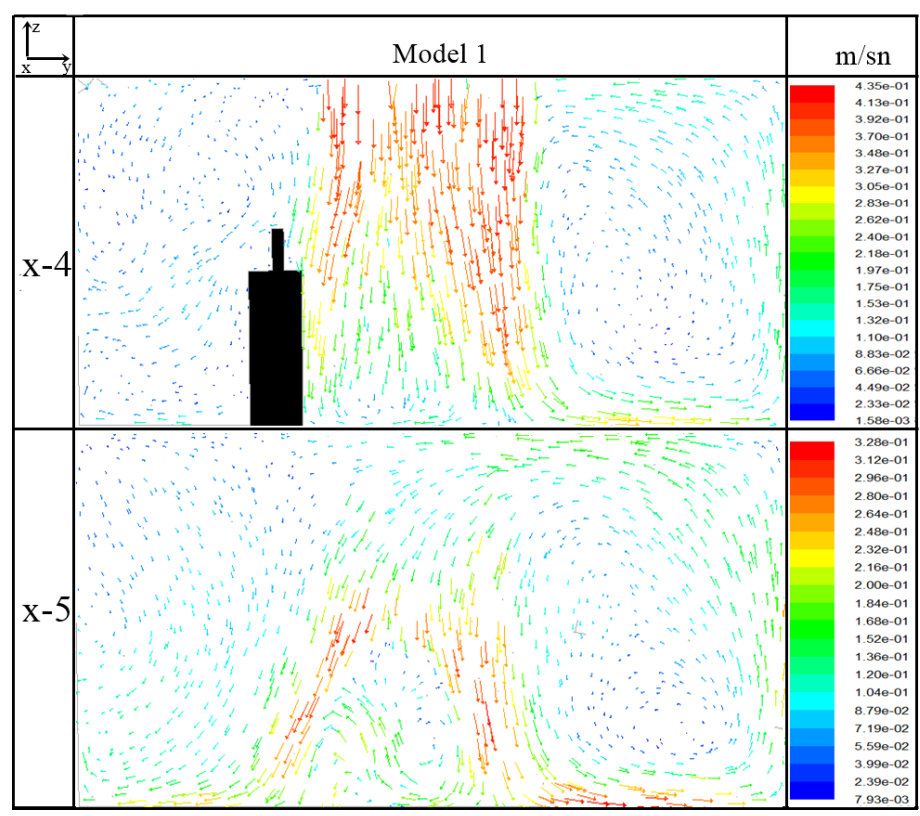

Şekil 10. Temmuz ayı için Model-1 'in kurulduğu ameliyathanenin x-4 ve $x$-5 düzlemlerinde hız vektörlerinin dağılımı

Şekil 10'da, $x$-4 düzleminde; ameliyathanenin orta kısmında $0,4 \mathrm{~m} / \mathrm{sn}$ hızında laminer akış bölgesi ve orta kısmın sağında bulunan alanda tabandan tavana kadar dönümlü hava bölgesi oluştuğu görülmektedir. Sol tarafında bulunan yerde ise monitör ve monitör standından dolayı dönümlü hava ve laminer akış oluşumunun engellendiği görülmektedir. Monitörün havadan askılı olması durumunda sağ tarafta oluşan dönümlü hava bölgesinin sol tarafta da oluşabileceği ve durgun ölü akış bölgelerinin oluşumunun engellenebileceği anlaşılmaktadır.

Şekil 10'da, x-5 düzleminde; üfleme menfezinin çıkışındaki laminer hava akışı etkisi azalmaya başlamıştır. Farklı hızlardaki düzensiz hava akış bölgeleri ameliyathaneye hakim durumdadır. Ölü akış bölgeleri oluşumu riski burada da görülmektedir.

$\mathrm{X}$-doğrultusu boyunca alına tüm düzlemlerden elde edilen hız vektörleri bir arada incelendiğinde $\mathrm{x}-1, \mathrm{x}-4$ ve x,5 düzlemlerinde laminer akış şartlarının sağlandığı görülmüştür. Ameliyathanede laminer akış görülmeyen kısımlarda ise düşük hıza sahip türbülanslı akış bölgelerinin oluştuğu görülmektedir. Temmuz ayı için Model-1'in kurulduğu ameliyathanenin z-1, z-2 ve z-3 düzlemlerinde hız vektörlerinin dağılımı Şekil 11 'de verilmektedir.

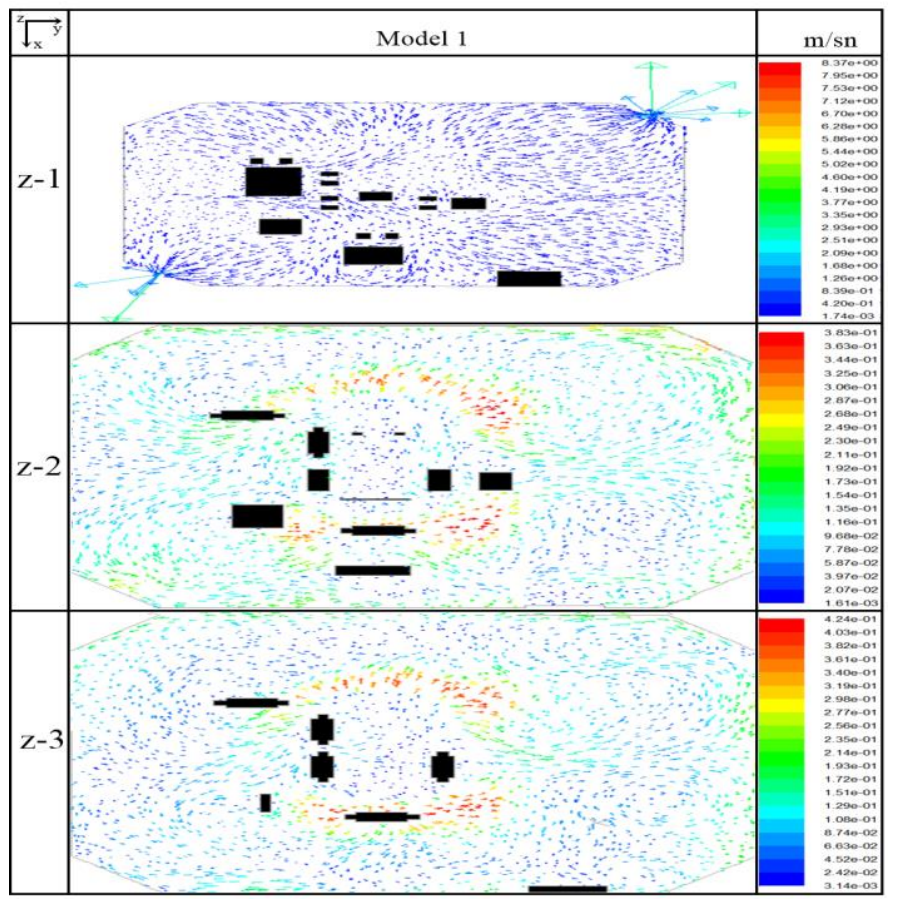

Şekil 11. Temmuz ayı için Model-1 'in kurulduğu ameliyathanenin z-1, z-2 ve z-3 düzlemlerinde hız vektörlerinin dağgllımı 
Şekil 11'de, z-düzlemlerinde emme menfezleri girişinde çok yüksek emiş hızları, kalan bölgelerde ise çok düşük hızların olduğu görülmektedir. z-2 ve z-3 düzlemlerinde ise personeli rahatsız edecek hızların oluşmadığı görülmektedir fakat ölü akış bölgelerinin oluşumu riski z-2 ve $z-3$ düzlemlerinde görülmektedir.

Model-2 için hava üfleme hızı sabit ve $1 \mathrm{~m} / \mathrm{sn}$ olarak alınmış ve sistemin analizleri bu kabul altında yapılmıştır. Ocak ayı için Model-2'nin kurulduğu ameliyathanenin x-1, x-2 ve x-3 düzlemlerinde hız vektörlerinin dağılımı Şekil 12'de verilmektedir.

Şekil 12'de, $x-1$ düzleminde; $0,1 \mathrm{~m} / \mathrm{sn}$ civarında düşük hıza sahip türbülanslı hava akış1 bölgeleri gözlenmektedir. Ölü akış bölgeleri oluşumu Model-1'de olduğu gibi Model-2'de de oluşmaktadır. Bu durum enfeksiyon riskini artırmaktadır. Sağ ve sol bölgelerde küçük hava döngüleri, orta bölgede ölü akış bölgeleri gözlenmektedir.

Şekil 12'de, x-2 düzleminde; cerrahi alet masası ve salonun sağ üst bölgesinde $0,1 \mathrm{~m} / \mathrm{sn}$ hıza sahip hava döngüleri, cerrahi alan üzerinde aynı hıza sahip türbülanslı akış bölgeleri görülmektedir.

Şekil 12'de, x-3 düzleminde; sağ bölgede aseptizörün emme menfezi girişinde $0,9 \mathrm{~m} / \mathrm{sn}$ hıza sahip vakum edilen havanın oluşturduğu vakum bölgesi, doktorun sirtı ile duvar arasında kalan bölgede $0,1 \mathrm{~m} / \mathrm{sn}$ hıza sahip büyük hava döngüsü bölgesi oluşumu gözlenmektedir.

Şekil 12'de, $x-1, x-2$ ve x-3 düzlemlerinde elde edilen analiz sonuçları bir arada ele alındığında aseptizör cihazı karşısında bulunan duvar boyunca türbülanslı akışın oluştuğu görülmektedir. Ocak ayı için Model-2'nin kurulduğu ameliyathanenin x-4 ve x-5 düzlemlerinde hız vektörlerinin dağılımı Şekil 13'de verilmektedir.

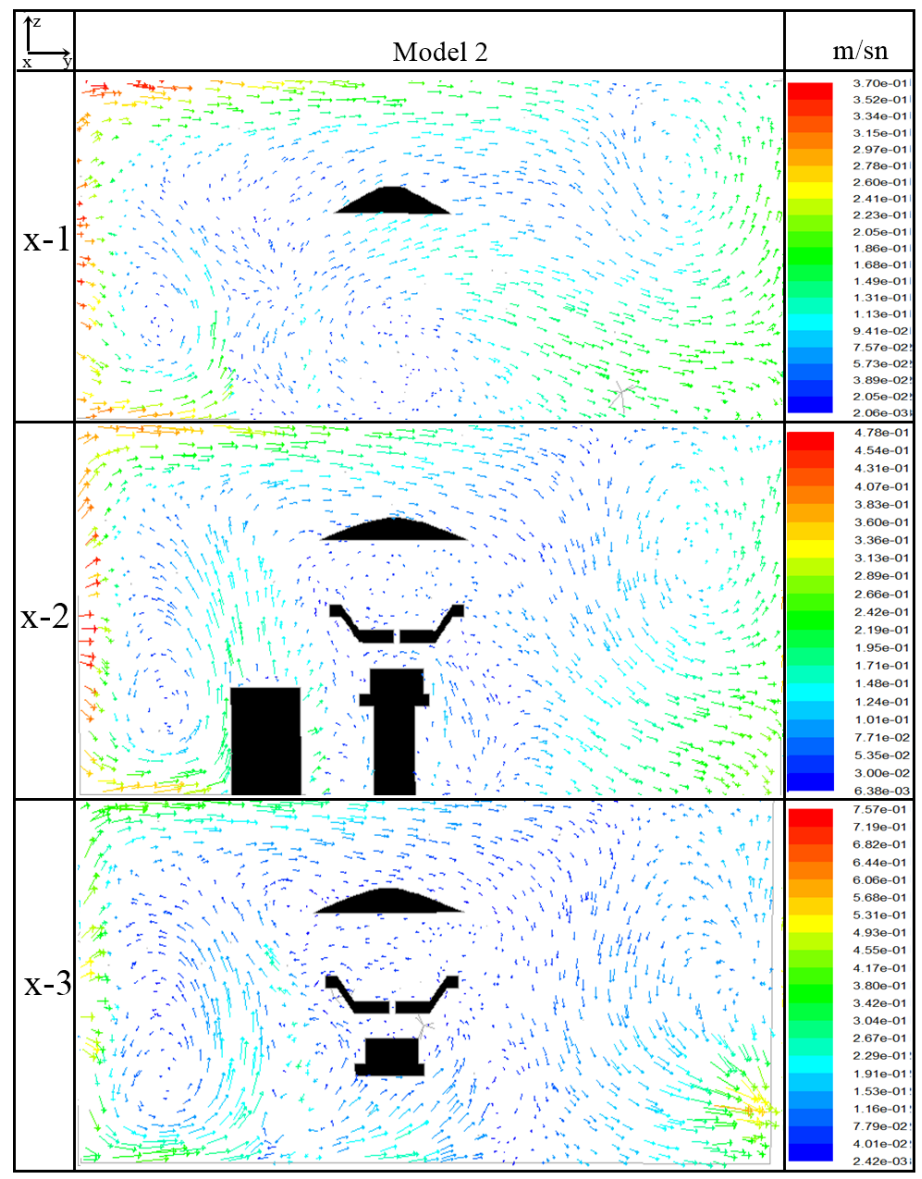

Şekil 12. Ocak ayı için Model-2'nin kurulduğu ameliyathanenin $x-1, x-2$ ve $x$-3 düzlemlerinde hız vektörlerinin dağıllımı 


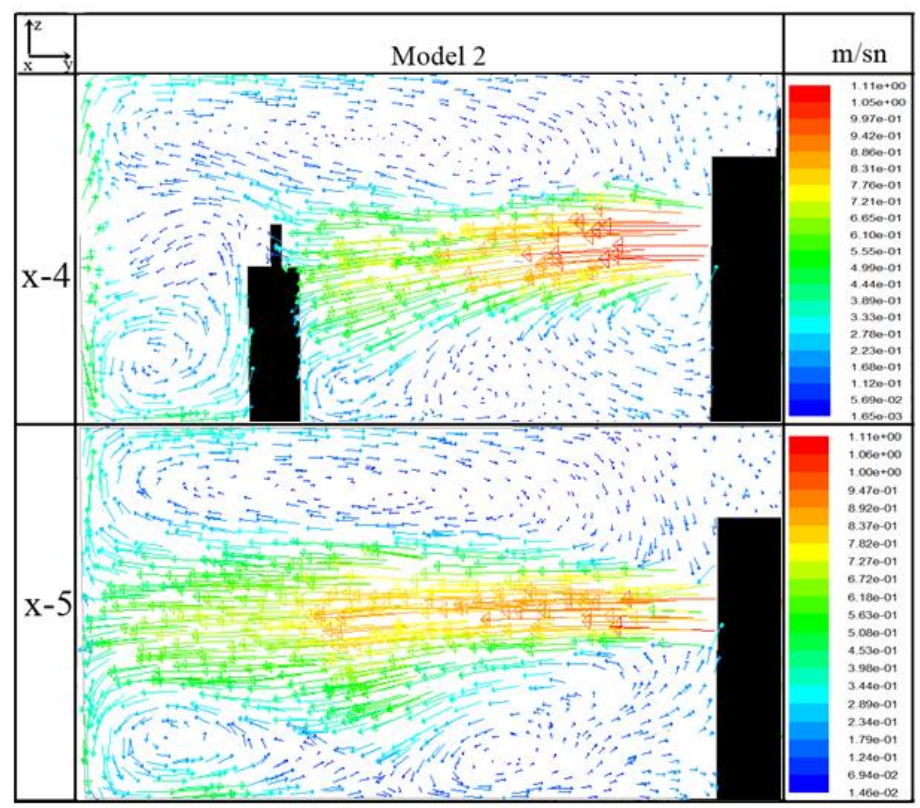

Şekil 13. Ocak ayı için Model-2'nin kurulduğu ameliyathanenin x-4 ve x-5 düzlemlerinde hız vektörlerinin dăgllımı

Şekil 13'de, x-4 ve x-5 düzlemlerinde; yüksek hızlı laminer akışlı bölgelerin oluştuğu görülmektedir. Monitör ve monitör standının arka bölgesinde laminer akış bölgesinin alt ve üst bölgelerinde ortalama $0,1 \mathrm{~m} / \mathrm{sn}$ hıza sahip hava döngüleri görülmektedir. Burada oluşan laminer akış, cerrahi alandaki kontaminasyonun uzaklaştırılmasına etki etmemektedir. Ek olarak anestezist $1 \mathrm{~m} / \mathrm{sn}$ 'lik yüksek hava akış hızlarına maruz kalması anestezisti rahatsız edecektir. Ocak ayı için Model-2'nin kurulduğu ameliyathanenin z-1, z-2 ve z-3 düzlemlerinde hız vektörlerinin dağılımı Şekil 14'de verilmektedir.

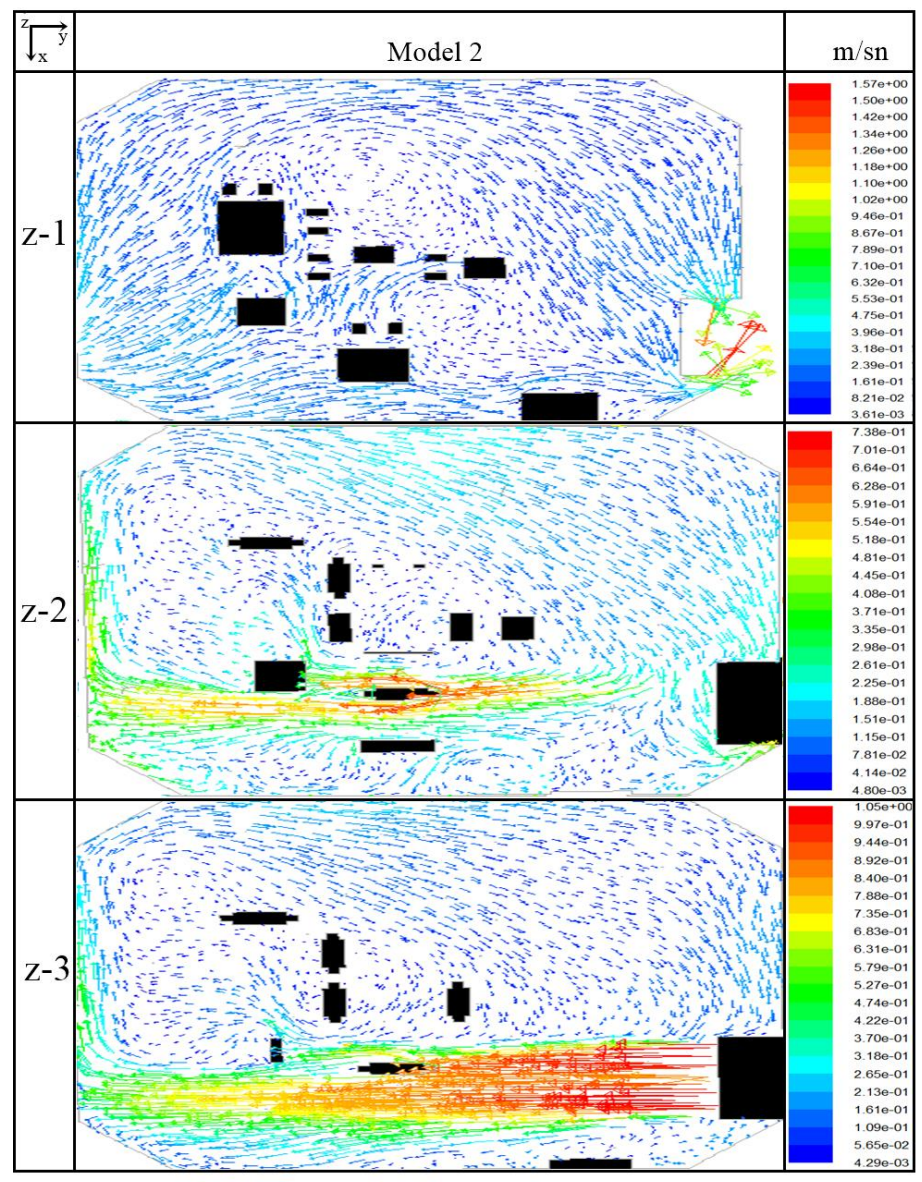

Şekil 14. Ocak ayı için Model-2'nin kurulduğu ameliyathanenin z-1, z-2 ve z-3 düzlemlerinde hız vektörlerinin dă̆llımı

Şekil 14'de, z-1 düzleminde; aseptizörün emme menfezleri girişinde 1,69 m/sn hıza ulaşabilen çok yüksek emiş hızları görülmektedir. Kalan bölgeler emme menfezleri girişinde görülen hızlara göre daha düşük olup $0,1 \mathrm{~m} / \mathrm{sn}$ civarındadır. 
Şekil 14'de, z-2 ve z-3 düzlemlerinde; yaklaşık 1 m/sn'lik hava akış hızı anestezisti rahatsız edebilecektir. Kalan diğer bölgelerde $0,1 \mathrm{~m} / \mathrm{sn}$ civarında, durgun sayılabilecek hava akış bölgeleri görülmekte olup enfeksiyon riskini artırmaktadır. Temmuz ayı için Model2’nin kurulduğu ameliyathanenin x-1, x-2 ve x-3 düzlemlerinde hız vektörlerinin dağılımı Şekil 15'de verilmektedir.

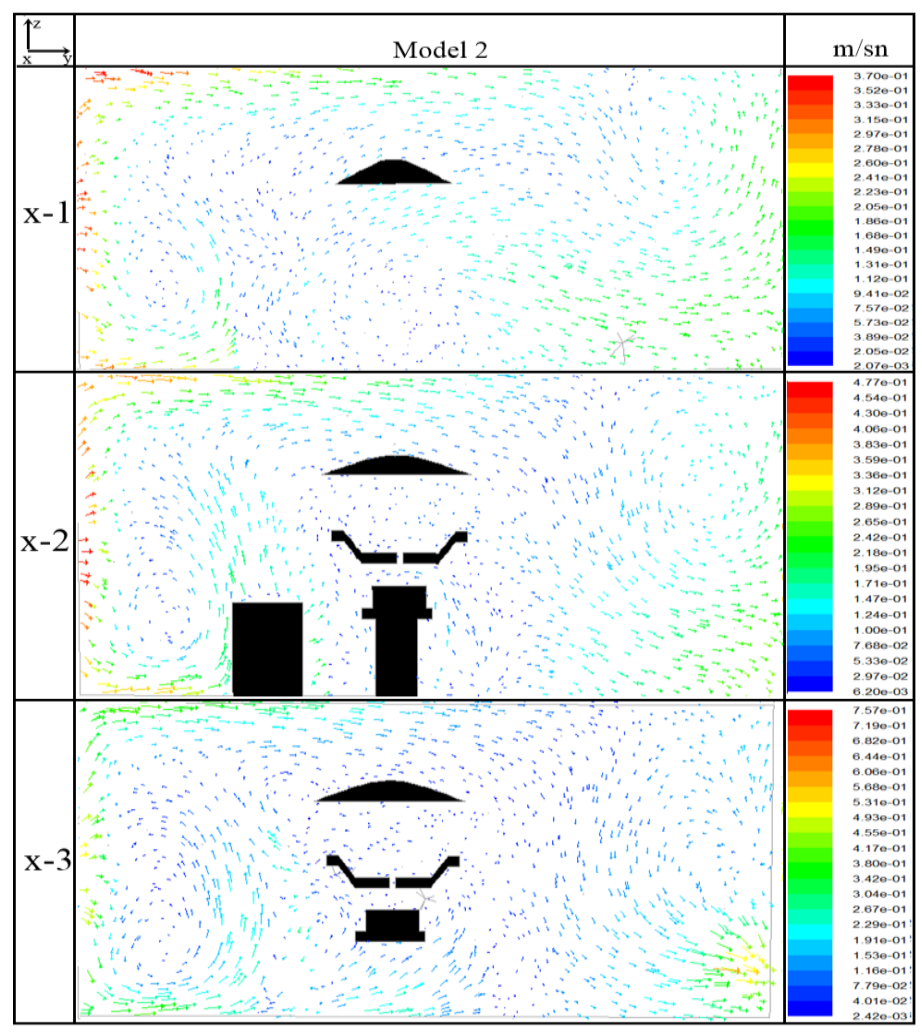

Şekil 15. Temmuz ayı için Model-2'nin kurulduğu ameliyathanenin $x$-1, x-2 ve x-3 düzlemlerinde hız vektörlerinin dă̆llımı

Şekil 15'de, x-1 düzleminde; $0,1 \mathrm{~m} / \mathrm{sn}$ civarında düşük hızlı türbülanslı hava akışı bölgeleri görülmektedir. Durgun hava bölgelerinde enfeksiyon riski mevcuttur.

Şekil 15 'de, x-2 düzleminde; cerrahi alet masası ve salonun sağ üst kısmında $0,1 \mathrm{~m} / \mathrm{sn}$ civarında hıza sahip hava döngüleri görülmektedir.

Şekil 15'de, x-3 düzleminde sağ bölgede aseptizörün emme menfezi girişinde $0,9 \mathrm{~m} / \mathrm{sn}$ hızında vakum edilen havanın oluşturduğu vakum bölgesi, doktorun sırtı ile duvar arasında kalan bölgede $0,1 \mathrm{~m} / \mathrm{sn}$ hıza sahip büyük hava döngüsünün meydana geldiği görülmektedir.

Şekil 15'de, x-1, x-2 ve x-3 düzlemlerinden elde edilen veriler bir arada ele alındığında tıpkı ocak ayında olduğu gibi, aseptizör cihazının karşısında bulunan duvar boyunca türbülanslı akış oluşumunun meydana geldiği görülmektedir. Cerrahi alan üzerinde ise laminer akış sağlanamamıştır. Temmuz ayı için Model-2'nin kurulduğu ameliyathanenin x-4 ve x-5 düzlemlerinde hız vektörlerinin dağılımı Şekil 16'da verilmektedir. 


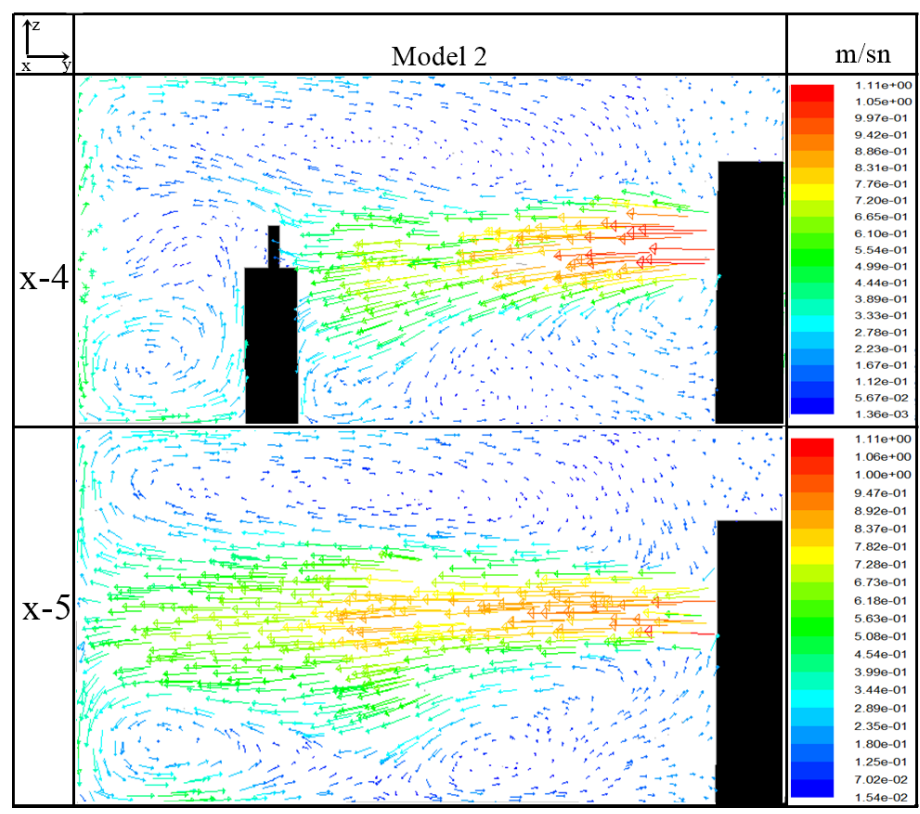

Şekil 16. Temmuz ayı için Model-2'nin kurulduğu ameliyathanenin $x-4$ ve $x$-5 düzlemlerinde hız vektörlerinin dağıllımı

Şekil 16'da, x-4 ve x-5 düzlemlerinde; 1 m/sn hızında laminer akışlı bölge dikkat çekmektedir. Monitör ve standı arkasında laminer akış bölgesinin alt ve üst bölgelerinde ortalama $0,1 \mathrm{~m} / \mathrm{sn}$ hıza sahip hava döngüleri görülmektedir. Laminer akışın, cerrahi alandaki kontaminasyonun uzaklaştırılması için sadece aseptizör çıkışında değil cerrahi alanda da olması gerekmektedir. $1 \mathrm{~m} / \mathrm{sn}$ 'lik yüksek hava akış hızları konfor şartlarının çok üzerinde olup bu durumun anestezisti rahatsız edeceği açıktır. Temmuz ayı için Model-2'nin kurulduğu ameliyathanenin z-1, z-2 ve z-3 düzlemlerinde hız vektörlerinin dağılımı Şekil 17'de verilmektedir.

Şekil 17'de, z-1 düzleminde; aseptizörün emme menfezleri girişinde 1,69 m/sn hıza ulaşabilen çok yüksek emiş hızları görülmektedir. Kalan bölgeler emme menfezleri girişinde görülen hızlara kıyasla daha düşük hava akış hızı gözlemlenmiş olup buralarada hava hızı yaklaşık $0,1 \mathrm{~m} / \mathrm{sn}$ civarında ölçülmüştür.

Şekil 17'de, z-2 ve z-3 düzlemlerinde; yaklaşık 1 m/sn'lik hava akış hızı anestezisti rahatsız etmektedir. Kalan diğer bölgelerde 0,1 $\mathrm{m} / \mathrm{sn}$ civarında, durgun sayılabilecek hava akış bölgeleri görülmekte olup buda enfeksiyon riskini artırmaktadır.

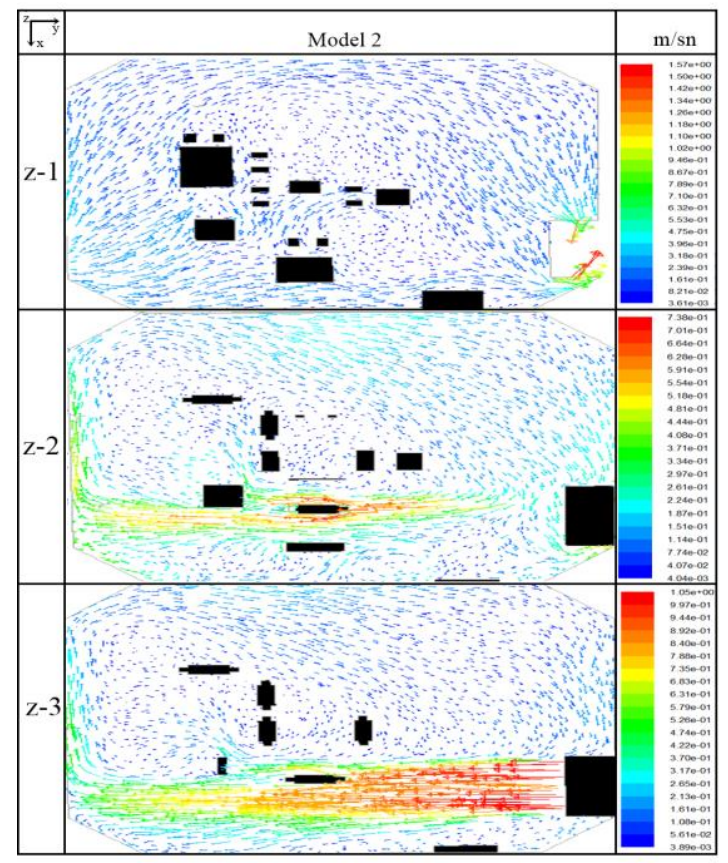

Şekil 17. Temmuz ayı için Model-2'nin kurulduğu ameliyathanenin z-1, z-2 ve z-3 düzlemlerinde hız vektörlerinin dă̆llımı

\section{Sonuç ve Öneriler}

Yapılan çalışmada, tasarlanan iki modelin (Model 1 ve Model 2) üfleme hızlarının ameliyathaneye etkileri, ANSYS Fluent 6.3 programıla sayısal olarak incelenmiştir. Model-1 tavandan üfleme yapan kenarlardan emme yapan bir iklimlendirme sistemi olarak 
tasarlanırken, Model-2 aseptizör yardımıyla hem üfleme hem emme yapan bir iklimlendirme sistemi olarak tasarlanmıştır. Her iki model içinde x-düzleminde 5, z-düzleminde 3 kesitte elde edilen veriler incelenmiştir.

Model-1'de incelenen kesitler bir arada ele alındığında ameliyathane lambalarının cerrahi alan üzerinde konumlandırılması sonucu düzensiz akışların meydana geldiği görülmüştür. Fakat üfleme hızı uygun olduğu için akış hızlarının rahatsız edici seviyelerde olmadığı görülmüştür.

Model 2'de ise incelenen kesitler sonucunda, cerrahi kadronun yüksek hava akış hızı sonucunda konfor şartlarının düşebileceği görülmüştür. Cerrahi alan üzerinde laminer akışın sağlanamamasından dolayı cerrahi alanda enfeksiyon oluşma riskinin arttı̆̆ 1 görülmüştür.

Model 2'de kullanılan aseptizör cihazı, ameliyathane içerisinde bulunduğu için filtrelerin bakımı ve değişmesi esnasında filtreler de bulunan partiküllerin ameliyathane salonuna dağılması durumunda ameliyathane de enfeksiyon oluşma riskini artacağı düşünülmektedir. Aseptizör cihazının ameliyathane salonunda bulunması, ameliyathane salonunda ki gürültünün artmasına da sebep olmaktadır. Gürültünün artması, cerrahi kadroyu rahatsız ettiği için bazı zamanlarda aseptizör cihazının kapatılmasına neden olabilecektir.

Her iki model de monitör, cerrahi alet masası, ilaç dolabı, anestezi makinası gibi cihazlar tavandan askılı olmadığı için hava sirkülasyonunu engellediği ve ölü akış bölgelerini oluşturduğu görülmüştür.

Model-2'de bulunan aseptizör cihazı, standartlarda belirtildiği gibi laminer hava akımı oluşturmadığı için ve enfeksiyon riski oluşumunu artırdı̆ı için en uygun iklimlendirme sisteminin Model-1'de ki tavandan üfleme kenarlardan emme yapan iklimlendirme sistemi olduğu görülmüştür.

\section{Teşekkür}

Mustafa Kemal Üniversitesi Fen Bilimleri Enstitüsü bünyesinde ve Dr. Öğr. Üyesi Yıldız KOÇ danışmanlığında yapılmış olan bu çalışma "İklimlendirilen Bir Ameliyathane Salonundaki Hava Akışının Sayısal Analizi” başlık tezden üretilmiştir. Yazarlar, çalışma boyunca katkılarından dolayı Üniversite ve Enstitü yönetimine teşekkürü bir borç bilmektedirler.

\section{Kaynakça}

[1] Tosun, M. F., Karakuş, C., Yağl1, H., \& Baltacıoğlu, H. (2015). Yoğun Bakım Ünitesinin Hijyenik İklimlendirme Hesabı ve Örnek Uygulama. TTMD Dergisi, 95, 30-36.

[2] Polat Y. (2011). Bir ameliyathane salonu iklimlendirilirken oluşan hava akımının sayısal analizi. Mustafa Kemal Üniversitesi, Yüksek Lisans Tezi Ocak-2011.

[3] Türk Cerrahı Tıp Sözlüğü, (Erişim tarihi: 28.03.2019), http://www.turkcerrahi.com/tip-sozlugu/ameliyathane/

[4] Ufat, H., Kaynakli, O., Yamankaradeniz, N., \& Yamankaradeniz, R. (2018). Investigation of the number of particles in an operating room at different ambient temperatures and inlet velocities. International Journal of Ventilation, 17(3), 209-223.

[5] Nastase, I., Croitoru, C., Vartires, A., \& Tataranu, L. (2016). Indoor environmental quality in operating rooms: an European standards review with regard to Romanian guidelines. Energy Procedia, 85, 375-382.

[6] Dasari, K. B., Albrecht, M., \& Harper, M. (2012). Effect of forced-air warming on the performance of operating theatre laminar flow ventilation. Anaesthesia, 67(3), 244-249.

[7] Polat, Y., Yağlı, H., \& Koç, Y. (2019). Bir Ameliyathanenin İklimlendirilmesi Süresince Hava Akımının Modellenmesi. European Journal of Science and Technology, (15), 420-432.

[8] Süngü, A. (2007). Ameliyathane havalandırma sistemleri IVF ve genetik laboratuvar havalandırma sistemleri. 5. Ulusal Sterilizasyon Dezenfeksiyon Kongresi, 466-485.

[9] Salim Ö. (2009). Hastane iklimlendirme sistemlerine genel bir bakış. 6. Ulusal Sterilizasyon Dezenfeksiyon Kongresi, 17-27.

[10] Çoşgun, A., Korkmaz, A., \& Doğdu, N. (2011). Hastanelerde Hijyenik Ortamlarda İç Hava Kalitesinin Araştırılması ve Modellenmesi (Antalya Örneği). III. Ulusal İklimlendirme Kongresi, 56-630.

[11] Taşdemir C. Hastane Ameliyathane ve Yoğun Bakımlarda Modüler Hijyen Klima Teknolojisi ve Enerji Maliyetleri. (Erişim tarihi: 20.02.2019) https://docplayer.biz.tr/7959664-Hastane-ameliyathane-ve-yogunbakimlarda-moduler-hijyen-klimateknolojisi-ve-enerji-maliyetleri.html

[12] Ayçam, İ. \& Yazıc1, A. (2017). Evaluation of operating room units within the context of green design criteria. Gazi University Journal of Science, 30(1), 1-15.

[13] Coşkun, Ö. (2007). Hastane hijyenik iklimlendirme sistemleri ile infeksiyon kontrolü. 3.Ulusal Yoğun Bakım Infeksiyonları Sетровуити.

[14] Hansen, D., Krabs, C., Benner, D., Brauksiepe, A., \& Popp, W. (2005). Laminar air flow provides high air quality in the operating field even during real operating conditions, but personal protection seems to be necessary in operations with tissue combustion. International journal of hygiene and environmental health, 208(6), 455-460.

[15] Provent Professional Ventilation systems. Paket Tip Hijyenik Klima Santrali Kataloğu. (Erişim Tarihi: 28.03.2019) https://docplayer.biz.tr/3422857-Paket-tip-hijyenik-klima-santrali.html.

[16] Memarzadeh, F., \& Manning, A. P. (2002). Comparison of operating room ventilation systems in the protection of the surgical site/Discussion. ASHRAE transactions, 108, 3. 